\title{
Az iskolaérettség mérésének összehasonlítása Magyarországon és Szerbiában
}

\section{Gyurcsik Anita - Fehér Orsolya - Földi Fanni}

Szegedi Tudományegyetem, Bölcsészettudományi Kar, Neveléstudományi Intézet, Neveléstudomány MA program

\begin{abstract}
Az elmúlt években egyre nagyobb figyelmet kapott az iskolaérettség, amely nagy szerepet játszik a gyermekek iskolai életében. Számos nehézséggel találkozhatnak azok a tanulók, akik nem rendelkeznek az iskolai tanuláshoz szükséges előfeltétel készségekkel. Tanulmányunkban összehasonlitásra kerül a Magyarországon fejlödésvizsgáló tesztek közül széles körben alkalmazott DIFER Programcsomag, továbbá a Szerbiában használt TIP-1 méröeszköz. Az elemzés során a két teszt hasonlóságait és különbségeit ismertetjük. Végezetül a tesztekhez kötödö fejlesztési lehetöségeket tárjuk fel.
\end{abstract}

Kulcsszavak: iskolaérettség, iskola-elökészités, DIFER, TIP-1, iskolaérettségi vizsgálat

Az elmúlt évek kutatásai egyre nagyobb hangsúlyt fektetnek az iskolaérettség fontosságára (Guernsey, Bornfreund, McCann és Williams, 2014), azonban problémássá válhat az iskolaérettség fogalmának meghatározása, hiszen nehéz megfogalmazni azt, hogy mit is jelent készen állni az iskolára (Aiona, 2005; Kende és Illés, 2007). Az iskolai felkészültség nagy szerepet játszik a gyermekek iskolai életében, különösképpen a kezdetekben. Nehézséggel találkozhatnak az iskola kezdetén azok a tanulók, akik nem érdeklődnek az iskola iránt és nem rendelkeznek az iskolai tanuláshoz szükséges előfeltétel készségeivel (Burchinal, Magnuson, Powell és Hong, 2015; Snow, 2006; Tymms, Jones, Albone és Henderson, 2009).

Tanulmányunkban bemutatjuk az iskolaérettség koncepcióját hazai és külföldi szakirodalom alapján. A magyarországi fejlődésvizsgáló tesztek közül a széles körben alkalmazott DIFER Programcsomagot ismertetjük, emellett a Szerbiában használt TIP-1 mérőeszközt mutatjuk be. Ezt követően áttekintjük, hogy milyen hasonlóságok és különbségek fedezhetőek fel a két tesztben. Végül azokról a fejlesztési módszerekről teszünk említést, amelyek segítséget nyújtanak a gyerekek közötti fejlettségbeli különbségek csökkentésében.

\section{Iskolaérettség}

Az iskolaérettség két különböző koncepciót kapcsol össze, az egyik a tanulásra való felkészültségre irányul, a másik pedig az iskolára való felkészültséget foglalja magába. A tanulásra való felkészültség azt a fejlettségi szintet jelöli, melynek révén a gyermek képessé válik arra, hogy különféle tananyagot megtanuljon. Azonban ez nem jelent egyet az iskolában való sikerességgel. Az iskolai felkészültség fogalma magába foglalja azt a fizikai, szellemi és szociális fejlődést, amely lehetővé teszi a gyermek számára, hogy teljesítse az iskolai követelményeket és elsajátítsa az iskolai tananyagot (Lewit és Schuurmann, 1995).

Az iskolaérettség meghatározása összetett folyamat, függ attól is, hogy a vizsgálatot végző személy mely területen tevékenykedik. Az iskolaérettséget három összetevőjével határozzák meg, ezek a tényezők a szomatikus, pszichés és a szociális érettség (Apró, 2013). Magyarországon ahhoz, hogy egy gyermek az óvodából az iskolába kerüljön, az alábbi feltételek megléte szükséges: a hatéves kor körül testileg egészségesen fejlődő gyermeknek megváltoznak a testarányai, mozgása összerendezettebb, harmonikus finommozgásra képes. Mozgását, viselkedését, valamint testi szükségleteit szándékosan irányítani tudja. Az óvodáskor végére 
a lelkileg egészségesen fejlődő gyermek nyitott érdeklődéssel várja az iskolát. Ebben az időszakban különös jelentősége van még a téri észlelés fejlettségének, a téri tájékozottságnak és a testséma kialakulásának. A szociálisan egészségesen fejlődő gyermek készen áll az iskolai élet és a tanító elfogadására, képes az együttműködésre és kapcsolatteremtésre (ÓNOAP, 2012). A szerb szakirodalom alapján a gyermek akkor válik iskolaéretté, ha fizikailag, szociálisan, affektíven és intellektuálisan elér egy meghatározott fejlettségi szintet. Képesnek kell lennie arra, hogy figyelmét 45 percen át fenntartsa, a pedagógus utasításait és előadását követni tudja, társaival és tanítóival kapcsolatot alakítson ki és együttműködjön, továbbá a sikeres iskolai előmenetelhez szükséges még egy bizonyos nyelvi fejlettségi szint (Tovilović és Baucal, 2007).

\section{Iskolaérettség mérése Magyarországon}

Abban az évben, melynek augusztus 31. napjáig a gyermek hatodik életévét betölti, tankötelessé válik. A 2011. évi CXC törvény a nemzeti köznevelésről 45. S (4) leírja, hogy tankötelezettség kezdetéről a) az óvoda vezetője, b) ha a gyermek nem járt óvodába az iskolaérettségi vizsgálat alapján a szakértői bizottság, c) az óvoda, az iskola vezetője vagy a szülő kezdeményezésére az iskolaérettségi vizsgálat alapján a szakértői bizottság dönt. Az iskolaérettségi vizsgálat egy komplex eljárás, amely során az adaptív viselkedést, a nyelvi, számolási, mozgás- és kognitív fejlettséget méri egyéni és csoportos helyzetekben egyaránt (Apró, 2013). Magyarországon az óvodapedagógusok nem végeznek kötelező jelleggel iskolaérettségi vizsgálatot, azonban kiemelt feladatként szerepel a gyermekek fejlődésének nyomon követése, melyhez különböző módszereket, eszközöket használhatnak fel, ilyen lehet a DIFER is (ÓNOAP, 2012).

$\mathrm{Az}$ óvodás- és kisiskoláskorú gyerekek alapkészségeinek vizsgálatára a Szegedi Tudományegyetem kutatói Nagy József vezetésével kifejlesztették a PREFER tesztrendszert a hetvenes években. A Preventív fejlettségvizsgáló rendszer 4-7 éves gyerekek számára lett kidolgozva. A tesztrendszer továbbfejlesztésének eredményeként jött létre a DIFER Programcsomag: Diagnosztikus fejlődésvizsgáló és kritériumorientált fejlesztő rendszer 4-8 évesek számára. Az elsődleges célja az elemi alapkészségek fejlesztésének segítése óvodás- és kisiskolás korban. Két nagyobb egységre bontható: a készségmérő tesztekre, illetve a készségek fejlesztését segítő módszerekre. A tesztek diagnosztikus képet adnak a készségek fejlettségéről, lefedve minden részkészséget és összetevőt (Józsa, 2016).

Alapkészségnek tekintjük azokat a készségeket, amelyek jelentős szerepet töltenek be valamely képesség, kompetencia vagy az egész személyiség fejlődésében. A DIFER a következő alapkészségek mérését és fejlesztését segíti: az írásmozgás-koordináció, a beszédhang-hallás, a relációszókincs, az elemi számolási készség, a tapasztalati következtetés, illetve a tapasztalati összefüggés-megértés és a szocialitás (Nagy, Józsa, Vidákovich és Fazekasné, 2004b).

Az első az írásmozgás-koordináció, amely az íráskészség elsajátításának előfeltétele. A kéz finommozgásának koordinációja teszi lehetővé az írás elsajátítását és használatát. Másodikként említhetjük a beszédhang-hallást, ami az olvasás és az írástanulás megkezdéséhez szükséges. „A beszédhanghallás spontán fejlődő készség, amely lehetővé teszi, hogy a beszédhangokat változó környezetben, önállóan észlelni tudjuk. Közreműködik a beszédészlelés során a tiszta hangejtésben, a szavakat alkotó hangsorok differenciálásában, a szó értelmezésében" (Nagy, Józsa, Vidákovich és Fazekasné, 2004b, 18. o.). A következő rész a relációszókincs, amely a hatékony szóbeli kommunikáció feltétele. A relációszókincs minden nyelv alapját képezi, ezek a szavak dolgok, tulajdonságok és folyamatok közötti viszonyokat, relációkat fejeznek ki. A mérés során a négy tesztváltozat mindegyike nyolc térbeli viszony megmutatását kéri (Nagy, Józsa, Vidákovich és Fazekasné, 2004b). Ezt követi a matematika tanuláshoz szükséges elemi számolási készség. Az elemi számolási készség alatt a százas számkörbeli számlálást és számolvasást, a húszas számkörbeli 
Az iskolaérettség mérésének összehasonlítása Magyarországon és Szerbiában

manipulatív számolást, a tízes számkörbeli számképfelismerést értjük (Józsa, 2014). Az ötödik rész a tapasztalati következtetés, ami a tudásszerzés, a tanulás és a gondolkodás feltétele. „A tapasztalati következtetés olyan egyszerű következtetési típusok megértését és használatát jelenti, amelyek mindennapi tartalmakkal és szituációkban is működnek, és a kommunikációban sajátos, de gyakran használt nyelvi szerkezetek segítségével jeleníthetők meg" (Vidákovich, 2008, 199. o). A hatodik részben a tapasztalati összefüggésmegértés megfelelő fejlettségét vizsgálják. Az összefüggések megismerésének, megértésének és alkalmazásának készségei a tudásszerző képesség, amely az iskolai eredményesség és az életminőség feltétele. A vizsgálat nyolc feladatból épül fel, a tesztbe kerülő összefüggés tartalmát meg kell magyarázni és ellenőrizni kell, hogy a gyermek érti-e. A fejlettségvizsgáló rendszer utolsó része a szocialitás mérése, mely a gyermekek társas készségeinek és motívumainak fejlettségét méri (Nagy, Józsa, Vidákovich és Fazekasné, 2004b).

A méréseket évente, esetleg félévente érdemes elvégezni. A teszt nem igényel speciális szakértelmet, óvónők és általános iskolai tanítók is felvehetik. Az adatfelvételhez három alkalom szükséges. Az első vizsgálati alkalom során az írásmozgás-koordináció és az összefüggés-megértés javasolt, ezt követően a beszédhanghallás és a -következtetés, majd a relációszókincs és az elemi számolás ajánlott (Nagy, Józsa, Vidákovich és Fazekasné, 2004a).

Jelenleg nincs egységes fejlődésvizsgáló rendszer, hanem az óvodapedagógusok döntik el, hogy hogyan követik a gyermekek fejlődését. Az óvodák 86 százaléka végez iskolaérettségi vizsgálatot, ezek közül 46 százalék használja a DIFER-t vagy korábbi változatát, a PREFER-t. Ehhez képest a többi vizsgálati eljárás alkalmazása sokkal kevésbé elterjedt (Apró, 2013). Az iskolák azokkal a tanulókkal végzik el a DIFER vizsgálatot, akiknek az elemi alapkészségeik lassabb ütemben fejlődnek. Az első osztályos gyerekek kb. 30 százalékánál látják szükségesnek elvégezni a DIFER mérést az iskolák (Józsa, 2016).

\section{Iskolaérettség mérése Szerbiában}

Évente több tízezer gyermek kezdi meg az első osztályt Szerbiában, így nagy segítség, ha az iskolába induló diákokról minél többet tudunk meg a tanítás kezdete előtt, ezáltal segítve az iskolai munka szervezését. Amennyiben hasznos információkat szereznénk a diákokról még az iskolakezdés előtt, azok alkalmazásával számos iskolai probléma kiküszöbölhető lenne (Ivić, Milinković, Pešikan és Bukvić, 2004).

Ebből a célból állították össze a TIP-1 (Test za ispitivanje prvaka) iskolaérettséget mérő tesztet 1989-ben, Belgrádban (Novović, Tovilović, Jovanović és Biro, 2009), amely az óvodás gyermekek kognitív képességeinek dinamikus értékelésére használható (Luković, Baucal és Tišma, 2013). A vizsgálat során a gyermekkel olyan mérést végeznek, melynek az adatfelvétele és az értékelése is rövid időt vesz igénybe (30 perc), továbbá az eszköz által mért eredmények alapján megoldhatóvá válnak olyan problémák, mint az osztályon belüli teljesítménybeli különbségek kiegyenlítése és a tanulási nehézségekkel rendelkező tanulók korai kiszűrése (Ivić, Milinković, Pešikan és Bukvić, 2004).

A teszt 6,8 éves kortól 7,4 éves korig vizsgálja a gyerekeket, legkorábban 6,2 éves kortól alkalmazható, mely során megállapításra kerül, hogy iskolaérett-e a gyermek (Ivić, Milinković, Pešikan és Bukvić, 2004). Az alapfokú oktatásról és nevelésről szóló törvény alapján Szerbiában „az iskolaév kezdetéig legalább hat és fél és legfeljebb hét és fél éves életkort betöltő összes gyermeknek iskolába kell iratkoznia" ( $A z S Z K$ Hiv. Közlönye, 26. o.). A tesztfelvételt az iskolapszichológus végzi az iskola megkezdése előtti tavaszon, szülői jelenlét nélkül (Tovilović és Baucal, 2007). Abban az esetben, ha a gyermek nem tud önállóan válaszolni a feltett kérdésre vagy nem tudja önállóan megoldani a feladatot, akkor a pszichológus előre meghatározott kérdések segítségével próbálja a megoldásra rávezetni. A vizsgálat során azonnal értékeli a gyermek válaszát és az eredményeket a válaszlapon rögzíti. Miután az egész tesztet megoldotta a gyermek, újból felteszik számára azokat a kérdéseket, amelyekre nem jól válaszolt (Luković, Baucal és Tišma, 2013). 
A TIP-1 teszt problémamegoldó feladatokon keresztül a logika, térbeli és időbeli viszonyok ismeretét egyszerűbb matematikai problémák megoldását, természetes és társadalmi, valamint logikai kapcsolatok megértését vizsgálja (Luković, Baucal és Tišma, 2013). A teszt öt részből tevődik össze: tudás, emlékezet, következtetés megfigyelés útján, verbális képességek és logikai műveletek (Ivić, Milinković, Pešikan és Bukvić, 2004; Novović, Tovilović, Jovanović és Biro, 2009). Az első rész (tudás) feladatainak szerkesztésénél arra törekedtek, hogy azok ne az információ reprodukciójára, hanem a megértésre irányuljanak. A második részben (emlékezet) klasszikus emlékezeti feladatok szerepelnek. Ehhez két feladatcsoport tartozik: az egyik a rajzok emlékezetben tartására, a másik pedig a számok felidézésére irányul. A harmadik rész feladatai (következtetés megfigyelés útján) során két részt különböztetnek meg: az első a sejtett alakzat felismerése, a második a rejtett alakzatok felfedezése a képsorozatban. A negyedik részben lévő feladatok (verbális képességek) további alrészeket foglalnak magukba: mondatok megértése, ellentétek, határozószók és a szorzatok. A feladatok az ötödik részben (logikai műveletek) a klasszikus, Piaget által kifejlesztett logikai gondolkodás vizsgálata alapján lettek megtervezve. Ez a rész négyféle feladatcsoportot tartalmaz: alakzatok csoportosítása, számosság, sorozat és egynemü osztályok rendezése (Ivić, Milinković, Pešikan és Bukvić, 2004).

A teszt eredményei által a gyermekek képességeiről nyerünk információt, amely megmutatja az egyéni különbségeket. Előrejelzést kapunk a későbbi iskolai teljesítményről, továbbá egyes tantárgyak eredményeiről, mint például a matematika és a szerb nyelv (Luković, Baucal és Tišma, 2013; Novović, Tovilović, Jovanović és Biro, 2009).

\section{Összehasonlító elemzés}

A következőkben a DIFER és TIP-1 iskolaérettséget mérő tesztek különbségeit és hasonlóságait ismertetjük. A két teszt ösz- szehasonlítása során a különbségek két fő csoportját különítettük el: az általános eltéréseket és a feladatok közötti különbségeket.

Általános eltérések közé sorolható a vizsgálatban résztvevő gyermekek életkora, ugyanis a DIFER 4-8 éves korosztályt mér, míg a TIP-1 6,8-tól 7,4 éves korig vizsgálja a gyermekeket. Különbségként említhetjük még a vizsgálatot végző személyt is, mely a DIFER esetében az óvodapedagógus vagy a tanító, a szerb teszt esetében pedig az iskolapszichológus. Fontos eltérés a tesztek felvételének ideje és a mérési alkalmak száma is, ugyanis Magyarországon három mérési alkalom, míg Szerbiában egy mérési alkalom ajánlott a teszt felvételéhez. A TIP-1 normaorientált teszt, mivel a gyerekek teljesítményét a minta átlagához viszonyítjuk. Ezzel szemben a DIFER egy kritériumorientált teszt, amely esetében a gyermekek fejlettségét a készségek optimális elsajátításához viszonyítják (Józsa, 2011).

A két mérőeszköz kézbevétele során a legfeltűnőbb az, hogy a DIFER teszt színes képekkel dolgozik, ezek alapján kell a gyerekeknek a feltett kérdésekre válaszolniuk. Ezzel ellentétben a TIP-1 alig használ képeket, így a gyermeknek fejből kell a pszichológus kérdéseire felelni.

Általánosan megfogalmazhatjuk, hogy a két teszt feladataiban hasonlóságokat és különbségeket is felfedeztünk, legfőképpen a feladatok csoportosításában figyelhetünk meg eltéréseket. A DIFER teszt relációszókincs részében megtalálható feladatok a TIP-1 teszt különböző részeiben jelennek meg. Ilyen például az évszakokra vonatkozó kérdés, amely a DIFER teszt relációszókincset vizsgáló részében, míg a TIP-1 esetében a tudást mérő részben található. A magyarországi teszt 7 fö részből épül fel, ezzel szemben a szerbiai teszt 5 részből, és ahhoz tartozó alrészekből tevődik össze.

Számos olyan feladatot találtunk a magyarországi tesztben, amely a másikban nem található. Ilyen például az, hogy a DIFER tartalmaz számképfelismerésre és számolvasásra vonatkozó feladatokat. Megjelennek benne az írásmozgás-koordináció fejlettségét mérő 
Az iskolaérettség mérésének összehasonlítása Magyarországon és Szerbiában

feladatok, míg a szerbiai tesztben a gyerekek ilyen feladatokkal nem találkoznak. Ehhez hasonló feladat a TIP-1 tesztben az, amikor a gyermekeknek ábrákat kell rajzolniuk emlékezetük alapján. A DIFER tapasztalati összefüggés-megértésre, valamint beszédhanghallásra vonatkozó feladatokat is tartalmaz, ilyen és ehhez hasonló feladatokat a szerbiai mérésben nem találtunk. A TIP-1 tesztben is találhatók olyan feladatok, amelyek a magyarországiban nincsenek. Ezek közül kiemelhető a tudás rész, amely rákérdez az olyan általános ismeretekre is, mint: "Hány éves leszel 1 év múlva? Mit csinál az orvos? Mire szolgál a fa gyökere?" stb. (Ivic, Milinkovic, Pesikan és Bukvic, 2004, 25. o.). A rajzok és a számok emlékezetből történő megismétlése, valamint a sejtett és rejtett alakzatok felismerése, hasonlóságok és ellentétek kiválasztása is a szerbiai teszt sajátosságai közé sorolható. A TIP-1 teszt további jellegzetessége a miért kérdés, ugyanis több feladatban meg kell indokolniuk a gyerekeknek a válaszaikat. Összességében megállapíthatjuk, hogy a TIP-1 teszt elsősorban a gyermekek tudására irányul, míg a DIFER inkább a képességek feltárását célozza meg.

A tesztek feladatai közt hasonlóságokat is felfedeztünk. Ezek közé sorolható, hogy mindkettőben található relációszókincsre vonatkozó feladat. Például, amikor a különböző határozókra kérdeznek rá (alatt, mellett, utolsó, harmadik), továbbá nagyságokra vonatkozó feladatok is jellemzőek (hosszabb, vékonyabb, stb.). A két teszt közös vonása az, hogy mindkettő tartalmaz számokhoz kapcsolódó feladatokat, de ezek a feladatok nem teljesen egyformák, továbbá a TIP-1 csak a tízes, míg a DIFER a százas számkörben mozog. A tapasztalati következtetés és a verbális képességek feladatai is hasonlítanak, bár a tapasztalati következtetés alapja a ha, akkor és a tehát séma, a verbális képességek pedig legföképpen a ki kérdésre irányulnak.

Mindkét teszt felvétele alatt a gyermekek folyamatos megfigyelés alatt állnak, viselkedésüket különböző szempontok alapján figyelik meg. A DIFER felvétele alatt gyermekek kitartását, az érzelmi viszonyulását és a koncentrációs készséget pontozzák (Nagy,
Józsa, Vidákovich és Fazekasné, 2004a). Ezzel szemben a TIP-1 tesztben a vizsgálatot végző személy a saját véleményét írja le a gyermekről röviden (Ivic, Milinkovic, Pesikan és Bukvic, 2004).

\section{Iskolaérettség és készségfejlesztés}

Komoly kihívást jelentenek a gyógypedagógia és a többségi pedagógia számára az azonos életkorú gyermekek közötti fejlettségbeli különbségek (Józsa, 2011; Józsa és Fazekasné Fenyvesi, 2006b). A kutatások eredményei azt jelzik, hogy a készségek fejlődése több évig tartó folyamat (Nagy, 1980; Nagy, Józsa, Vidákovich és Fenyvesi, 2004b). A különbségek kialakulásában a környezeti tényezők nagy szerepet játszanak, ugyanis kimutatható a hátrányos helyzetű gyermekek elmaradása. Az alacsonyabb iskolai végzettséggel rendelkező szülők gyermekei több mint két évnyi fejlettségbeli megkésettséggel kezdik meg az iskolát, mint a felsőfokú végzettséggel rendelkező családok gyermekei (Józsa, 2004). A hátrányos helyzetből bekövetkező elmaradás csökkenthető az elemi alapkészségek játékos fejlesztésével. Fontos, hogy a szülők rendszeresen meséljenek gyermeküknek, illetve beszélgetéssel és játékkal töltsék a szabadidejüket (Józsa és Zentai, 2007; Nyitrai, 2016).

Az iskolai évek alatt azok a diákok, akiknek a képességeik lassabb ütemben fejlődnek, lemaradnak a társaiktól. Az elemi alapkészségek lassabb fejlődése következtében az iskolai tanulás nehezítetté válik számukra, így sok gyermek a szakértői biztosság véleménye alapján speciális tantervű iskolába kerül (Józsa és Fazekasné Fenyvesi, 2006a). A DIFER programcsomag a gyógypedagógia fontos eszközévé vált, mivel a tanulásban akadályozott tanulók fejlettségének feltárására is alkalmas (Józsa, 2011).

Az utóbbi évek kutatásai arra is felhívták a figyelmet, hogy a DIFER tesztek az értelmileg akadályozott tanulók vizsgálatára is használhatók (Radványi, Fazekasné és Radicsné, 2012). A tanulási zavar DIFER tesztekkel való feltárásáról még nincsenek mérési eredmények, ugyanis ezek a nehézségek többnyire az 
iskola későbbi éveiben jelentkeznek. Longitudinális vizsgálatokkal lehetne a DIFER előre jelző funkcióját feltárni (Józsa, 2016).

A DIFER egyik célja a készségfejlődés segítése. A tesztek diagnosztikus eredményeket nyújtanak a készségek fejlettségéről, ezáltal egyértelműen meg lehet határozni a fejlesztési tennivalókat. A gyerekek eredményeinek dokumentálására a Fejlődési mutató (Nagy és Józsa, 2016) használható, ami jelzi, hogy mely készségeket sajátították el, és melyek azok a területek, amelyek további fejlesztést igényelnek. A fejlesztő programokban alkalmazott módszerek, játékok, gyakorlati ötletek könyvsorozat formájában jelentek meg (Fazekasné Fenyvesi, 2006; Józsa, 2014; Józsa, Zentai és Hajdúné, 2017; Miskolcziné és Nagy, 2006; Nagy, Nyitrai és Vidákovich, 2009; Zsolnai, 2006).

A DIFER fejlesztőfüzetek célja az egyéni fejlesztéshez szükséges gyakorlatok biztosítása az iskolába készülő vagy az iskolát kezdő gyermekek számára (Kriston-Bordi, 2011). Ezek a füzetek négy terület fejlesztésére irányulnak: írás, betűtanulás, számolás és tájékozódás. A gyerekek egyéni munka során az óvodában, az iskolában vagy otthon is elvégezhetik ezeket. A feladatokat a füzetben megjelenő sorrendben kell kitölteni, mert a fejlesztés elvárt lépéseinek megfelelően követik egymást (Kriston-Bordi, 2008). Az Írás munkafüzet egyénileg fejleszti azokat a gyerekeket, akinél még kialakulatlan írásmozgás- és szem-kéz koordináció (Kriston-Bordi, 2008a). A Betűtanulás munkafüzet feladatai a betűk felismerésének elmélyítése mellett azokat az alapkészségeket is segítik, amelyek szükségesek az eredményes iskolai munkához, például a kézmozgás koordinációjának fejlesztése, az irányok, a síkbeli tájékozódás, a számolás, számlálás (Kriston-Bordi, 2011). A Számolás füzet feladatai alkalmasak a még kialakulatlan számfogalom fejlesztésére, a manipulatív számolás alapjainak elsajátítására, emellett tartalmaz számlálással, mennyiségek összehasonlításával kapcsolatos gyakorlatokat is (Kriston-Bordi, 2008b). A Tájékozódás fejlesztőfüzet feladatai az irányfogalom fejlesztésére, a síkbeli tájékozódás gyakoroltatására, a tárgyak és események közötti vi- szonyok felismertetésére, a relációszókincs bővítésére alkalmasak (Kriston-Bordi, 2010).

A TIP-1 nem foglalkozik fejlesztéssel, azonban a Vajdaságban is találhatunk fejlesztési programot (Ivić, Milinković, Pešikan és Bukvić, 2004). 2010-ben végzett iskolaérettség vizsgálat alapján megállapították, hogy néhány gyereknek még az óvodában lenne a helye és komoly segítségre van szükség ahhoz, hogy a társaihoz fel tudjon zárkózni. A Vajdasági Pedagógiai Intézet kifejlesztett egy olyan módszert, amely a tanulási nehézséggel küzdő gyermekek fejlesztésére irányul, az iskolaérettség vizsgálatához köthető. A fejlesztést a tanítók megfelelő felkészültséggel is elvégezhetik, a diagnózis elkészítéséhez szakember szükséges (Tóth, 2011).

\section{Összegzés}

A sikeres iskolakezdés nagyban meghatározza egy gyermek további iskola eredményességét, számos iskolai probléma megoldásra kerülne, amennyiben elegendő hasznos információt szereznénk a gyermekekről még az iskola megkezdése előtt. Az eredményes iskolakezdés feltételeinek megteremtésére így egyre több kutatási és fejlesztési programot dolgoznak ki, melyek segítségével a fejlődési folyamat nyomon követhető. Az óvodákban alkalmazásra kerülnek iskolaérettséget, valamint fejlődést vizsgáló tesztek, ilyen a Szerbiában is használandó TIP-1, valamint a magyarországi DIFER fejlődésvizsgáló rendszer.

A kétfajta teszt összehasonlítása során több különbséget és hasonlóságot is felfedeztünk. Az általános eltérések közé sorolhatjuk a vizsgálatban résztvevő gyermekek életkorát, a tesztek felvételének idejét és a vizsgálati alkalmak számát, valamint a vizsgálatot végző személyt is. Továbbá elmondhatjuk, hogy a legnagyobb különbségeket a feladatok csoportosításában, illetve típusában találtuk. Több olyan feladat is megtalálható az egyikben, ami a másikban egyáltalán nem jelenik meg, illetve a hangsúly is más és más típusú feladatokra tevődik. Az eltérések mellett hasonlóságokat is felfedeztünk, ezek közé sorolható a relációszókincsre vonatkozó, valamint a számokhoz kapcsolódó 
Az iskolaérettség mérésének összehasonlítása Magyarországon és Szerbiában

feladatok, valamint a tapasztalati következtetés és a verbális képességek részfeladatai.

A DIFER egyik fó céljaként említhető a készségfejlődés elősegítése. A tesztek alkalmazása során nyert diagnosztikus eredményekből egyértelműen meghatározhatjuk a fejlesztési feladatokat, melyhez a DIFER módszertani könyvsorozat, valamint a DIFER fejlesztő füzetek vannak segítségünkre. A TIP-1 teszthez nem kapcsolódik fejlesztő program, de Szerbiában is találhatunk olyan módszereket, amelyek a gyerekek fejlesztésére irányulnak.

\section{Felhasznált irodalom}

2011. Évi CXC. törvény a nemzeti köznevelésröl 45. $S$ (4)

URL: https://net.jogtar.hu/jr/gen/hjegy_doc. cgi?docid=A1100190.TV

A Szerb Köztársaság Hivatalos Közlönye (55/2013): Törvény az alapfokú oktatásról és nevelésről.

URL: http://www.mnt.org.rs/dokumentumok/ hasznos-tartalom/torvenyek-es-egyeb-jogidokumentumok-magyar-nyelven

Apró Melinda (2013): A hazai iskolaérettségi vizsgálatok gyakorlata napjainkban. Iskolakultúra, 23. 1. sz. 52-71.

Burchinal, M., Magnuson, K., Powell, D., \& Hong, S. S. (2015): Early childcare and education. In: Lerner, R., Bornstein, M. és Leventhal, T. (szerk.): Handbook of child psychology and developmental science. Volume 4. Ecological settings and processes, Chapter 6. Wiley, Hoboken, NJ. 1-45.

Fazekasné Fenyvesi Margit (2006): A beszédhanghallás fejlesztése 4-8 éves életkorban: módszertani segédanyag óvodapedagógusoknak és tanitóknak. Mozaik Kiadó, Szeged.

Guernsey, L., Bornfreund, L., McCann, C. \& Williams, C. (2014): Subprime learning: Early education in America since the great recession. New America/Education Policy Program, 1-25.

Ivić, I., Milinković, M., Pešikan, A. @ Bukvić, A. (2004): Test za ispitavanje prvaka (TIP-1). Centar za primenjenu psihologiju, Beograd.

Józsa Krisztián (2004): Az első osztályos tanulók elemi alapkészségeinek fejlettsége: Egy longitudinális kutatás első mérési pontja. Iskolakultúra, 14. 11. sz. 3-16.
Józsa Krisztián (2011): Híd a többségi és a gyógypedagógia között: a DIFER Programcsomag. In: Papp Gabriella (szerk.): A diagnózistól a foglalkozási rehabilitációig. Eötvös Kiadó, Budapest. 37-58.

Józsa Krisztián (2014): A számolás fejlesztése 4-8 éves életkorban. Mozaik Kiadó, Szeged.

Józsa Krisztián (2016): Kihívások és lehetőségek az óvodai fejlesztésben. Iskolakultúra, 26. 4. sz. 59-74.

Józsa Krisztián és Fazekasné Fenyvesi Margit (2006a): A DIFER Programcsomag alkalmazási lehetősége tanulásban akadályozott gyermekeknél - I. rész. Gyógypedagógiai Szemle, 34. 2. sz. 133-141.

Józsa Krisztián és Fazekasné Fenyvesi Margit (2006b): A DIFER Programcsomag alkalmazási lehetősége tanulásban akadályozott gyermekeknél - II. rész. Gyógypedagógiai Szemle, 34. 3. sz. 161-176.

Józsa Krisztián, Zentai Gabriella és Hajduné Holló Katalin (2017): A gondolkodás fejlesztése 4-8 éves életkorban: Módszertani kézikönyv szülőknek, óvodapedagógusoknak, tanítóknak. Mozaik Kiadó, Szeged.

Kende Anna és Illés Anikó (2007): A rugalmas beiskolázás és az oktatási szakadék összefüggései. Új Pedagógiai Szemle, 57. 11. sz. 17-41.

Kormányrendelet az Óvodai nevelés országos alapprogramjáról (363/2012. XII. 17)

URL: https://net.jogtar.hu/jr/gen/hjegy_doc. cgi?docid $=$ a1200363. kor

Kriston-Bordi Zsuzsanna (2008a): DIFER fejlesztö füzetek - Írás. Mozaik Kiadó, Szeged.

Kriston-Bordi Zsuzsanna (2008b): DIFER fejlesztő füzetek - Számolás. Mozaik Kiadó, Szeged.

Kriston-Bordi Zsuzsanna (2010): DIFER fejlesztő füzetek - Tájékozódás. Mozaik Kiadó, Szeged.

Kriston-Bordi Zsuzsanna (2011): DIFER fejlesztö füzetek - Betütanulás. Mozaik Kiadó, Szeged.

Lewit, E. M. \& Schuurmann, B. L. (1995): School readiness. The Future of Children, 5. 2. sz. 128-139.

Lukovic, S., Baucal, A. \& Tisma, B. (2013): Dinamicko procenivanje zone narednog razvoja testom za ispitivanje prvaka - 1 (TIP-1). Primenjena Psihologija, 6. 4. sz. 371-383.

Miskolcziné Radics Katalin és Nagy József (2006): Az írásmozgás- koordináció fejlesztése 4-8 éves életkorban. Mozaik Kiadó, Szeged. 
Gyurcsik Anita - Fehér Orsolya - Földi Fanni

Nagy József és Józsa Krisztián (2016): DIFER Fejlődési mutató. Mozaik Kiadó, Szeged.

Nagy József, Józsa Krisztián, Vidákovich Tibor és Fazekasné Fenyvesi Margit (2004a): DIFER Programcsomag: Diagnosztikus fejlödésvizsgáló és kritériumorientált fejlesztö rendszer 4-8 évesek számára. Mozaik Kiadó, Szeged.

Nagy József, Józsa Krisztián, Vidákovich Tibor és Fenyvesi Margit (2004b): Az elemi alapkészségek fejlödése 4-8 éves életkorban. Mozaik Kiadó, Szeged.

Nagy József, Nyitrai Ágnes és Vidákovich Tibor (2009): Fejlesztés mesékkel: Az anyanyelv, a gondolkodás fejlödésének segitése mesékkel 4-8 éves életkorban. Mozaik Kiadó, Szeged.

Nyitrai Ágnes (2016): Mese és mesélés. Iskolakultúra, 26. 4. sz. 75-83.

Novović, Z., Tovilović, S., Jovanović, V. \& Biro, M. (2009): Validacija testa zrelosti za školu. Primenjena psichologija, 2. 2. sz. 129-147.

Radványi Katalin, Fazekasné Fenyvesi Margit és Radicsné Szerencsés Teréz (2012): A pedagógiai diagnosztika lehetőségei enyhén és középsúlyosan értelmi fogyatékos gyermekek együttnevelésében. Gyógypedagógiai Szemle, 40. 3. sz. 214-225.
Shelli, A. (2005): Assesing School Readiness. Educational Perspectives, 38. 1. sz. 47-50.

Snow, K. L. (2006). Measuring school readiness: Conceptual and practical considerations. Early Education and Development, 17. 1 sz. 7-41.

Tóth Karolina (2011): A tanulási nehézséggel küzdő gyermek fejlesztése. Iskolakultúra, 21. 2-3. sz. 3-16.

Tovilović, S. és Baucal, A. (2007): Procena zrelosti za školu. Kako pristupiti problemima procene zrelosti $i$ adaptacije marginalizovane dece na školu. Centar za primenjenu psihologiju Društva psihologa Srbije, Beograd.

Tymms, P., Jones, P., Albone, S. \& Henderson, B. (2009): The first seven years at school. Educational Assessment, Evaluation and Accountability, 21. 1. sz. 67-80.

Vidákovich Tibor (2008): A tapasztalati következtetés fejlődése az óvodától a középiskoláig, Magyar Pedagógia, 108. 3. sz. 199-224.

Zsolnai Anikó (2006): A szocialitás fejlesztése 4-8 éves életkorban. Mozik Kiadó, Szeged.

\section{Assessing school readiness in Hungary and Serbia}

In the past years school readiness has got more and more attention that has a big effect on a child's school experiences. Those students who do not have the necessary skills before entering school face numerous problems. In this text we compare the Hungarian and Serbian ability tests and describe the similarities and the differences that we found between them. Finally we summarize the developing possibilities linked to these tests.

Keywords: school readiness, maturity, DIFER, TIP-1, child development

Gyurcsik Anita - Fehér Orsolya - Földi Fanni (2017): Az iskolaérettség mérésének összehasonlítása Magyarországon és Szerbiában. Gyermeknevelés, 5. 3. sz., 93-100. 